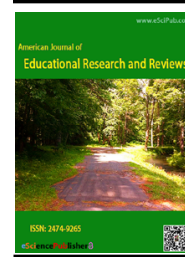

American Journal of Educational Research and Reviews

(ISSN:2474-9265)

\title{
The Need for Pre-retirement Vocational Education Training for Workers in Tertiary Institutions in Ekiti State, Nigeria
}

\author{
Dr. B. G. Agboola', Dr. M.A. Aina², Dr. I. P. Ogundola ${ }^{3}$, Dr. C. J. Ayodele ${ }^{4}$
}

${ }^{1}$ Department of Adult Education and Community Development,Faculty of Education, Ekiti State University, Ado Ekiti; ${ }^{2}$ Vocational and Technical Education Department, Faculty of Education, Ekiti State University, Ado Ekiti; ${ }^{3}$ Department of Vocational and Technical Education, Faculty of Education,Ekiti State University, Ado-Ekiti; ${ }^{4}$ Department of Guidance and Counselling, Faculty of Education, Ekiti State University, Ado-Ekiti

\section{ABSTRACT}

This study examined the need for pre-retirement vocational education training for workers in tertiary institutions in Ekiti State. Descriptive research design was used for this study. The population of the study was 9,523 , made up of academic and non-academic members of staff in the four public tertiary institutions in the state. Five per cent (5\%) of the total population was used as the sample for the study using proportionate sampling technique. Thus, the sample for the study was 476 members of staff. A set of questionnaire titled "Questionnaire on Pre-retirement Education Training for Tertiary Institution Workers in Ekiti State (QPETTIW) was administered on the respondents. All the administered questionnaires were returned, mean and standard deviation were used to answer the four research questions. The finding revealed that there were economic, social and psychological needs for pre-retirement vocational education training for workers in public tertiary institutions in Ekiti State. Thus, it was recommended that institutional authorities should incorporate pre-retirement vocational training/education into their staff development programme, among others.

\section{${ }^{*}$ Correspondence to Author:}

Dr. B. G. Agboola

Department of Adult Education and Community Development,Faculty of Education, Ekiti State University, Ado Ekiti.

How to cite this article:

B. G. Agboola, M.A. Aina, I. P. Ogundola, C. J. Ayodele. The Need for Pre-retirement Vocational Education Training for Workers in Tertiary Institutions in Ekiti State, Nigeria. American Journal of Educational Research and Reviews, 2020,5:72.

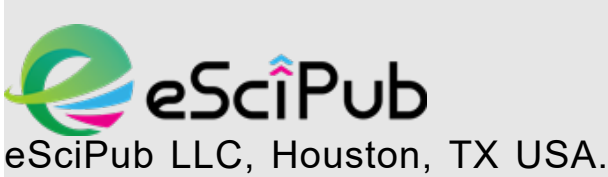

Keywords: Pre-retirement, Vocational Education; Training, Website: https://escipub.com/ Workers, Tertiary Institution, Retirement. 


\section{Introduction}

The growing concern of every personnel of the Nigerian working population who are potential retirees sooner or later after their work career, is the discouraging experience that the present retirees face due to irregular payment of their gratuities and pension benefits in Nigeria. Financial concern is a major one out of the numerous apprehensions of retirees. This explains one of the crucial reasons why some employees work past retirement age (Agboola, Adedokun and Adeyemo, 2017). The era of Pay As You Go Defined Benefit Scheme is gone in Nigeria. What obtains now is Contributing Pension Scheme backed up by the Pension Act, 2014. Some other challenges of retirees seem to include decreased strength, deteriorated health condition, physical disabilities, dividing status, loneliness, anxiety about a residential home and ageing. In view of the highlighted assumed problems, it is expedient for prospective retirees to prepare financially and psychologically towards this necessary end. Becker, Trail, Lamberts and Jimmerson (1983) submitted that "many of the problems facing retired people today could have been avoided through proper pre-retirement education and planning. Early training for retirement could be a preventive measure for avoiding many problems and depression in retirement.

Ageing and retirement are irrevocable occurrences in the life of individual employees whether in the public or private sector. As retirement is mandatory in public and private services, ageing is equally a natural development which affects or slows down the effectiveness and efficiency of the body system. This may even bring about retirement sooner than normal, hence, planning for the retirement period, which is equally the time of old age is a worthwhile venture when employees are still very active in service.

Odu, Ayodele and Adedayo (2014) are of the opinion that capacity building is a necessary process of development and strengthening the skills, abilities, processes and resources that organizations, institutions and communities need to survive, adapt and strike in the fast changing world. In which case, it is the element that gives mobility, flexibility and functionality of a programme of an organization to adapt to changing needs of the population.

Pre-retirement education is a phenomenon that will impart and equip the employees in workplaces with psychological knowledge, skills and abilities that promote successful transition from active service to retirement. This type of education will help every potential retirees in addressing the anxiety about attaining financial security, good health, satisfying interpersonal relationship, participation in leisure activities, and some forms of involvement in work, whether in a voluntary or paid capacity after retirement (Ubangha and Akinyemi, Kim and Feldman, 2000).

As employers globally recognize that between the service years and retirement; workers are considered most energetic and useful as their labour time are spent for their employer(s), there should also be an adequate plan by the employers for life after retirement for these workers who would have been weak by then especially in Nigeria context (Ali, 2014). Providing training or education to workers at the tail end of their service may not yield the expected positive result, the training is expected to be incorporated right from the entry point through their work career in a continuous manner. Such integration would have prepared the employees psychologically, mentally, financially and with good knowledge of the venture to undertake after retirement for social security.

Prevalent situation in Nigeria as regards the ugly experiences of pensioners and pervasive corruption in the pension scheme have made most workers to be faced with lots of psychosomatic problems and some exhibit psycho-phobic reactions because of the gloomy future ahead of them. Thus, pre-retirement education seems to equip young and old https://escipub.com/american-journal-of-educational-research-and-reviews/ 


\section{B. G. Agboola et al., AJERR, 2020; 5:72}

workers with the necessary wherewithal to prepare and smoothly graduate into retirement phase without any apprehension.

In view of this, it may not be out of place if workers are introduced to trade subjects that are listed in the National Policy of Education (2017). Thus, Ugwuanyi, Ugwu and Ezeh in Aina (2019) noted the need for the development of personal skills, and attributes, communication and computation skills technological literacy skills, employability skills and broad specific occupational skills and knowledge that may improve human capital development even after official retirement.

As financial responsibility is primary during retirement period, so are the realities of isolation/loneliness, physical disabilities, dwindling status and deteriorated health condition, among other factors are of concern during this advanced facet. Kleop and Hendry (2007) observed that existing retirement planning consists of little more than financial advice, and does not cover preparation for the social, emotional and health challenges of later life. They observed that life beyond work requires developing a range of interests, hobbies and skills that will facilitate their transition much earlier in the life course, not during the process of retirement.

Cusson (2017) also submitted that nonfinancial aspect of creating happy retirement is equally noteworthy as the financial readiness of planners (prospective retirees). He noted that during this later period in life, people experience loneliness and depression as a result of living alone or due to lack of close family ties which results in inability to actively participate in community activities. Thus, there is need to make advance preparation to cope with future life shift in the areas of social relationship cum interaction, health issues, employment and daily activities with the present working population in tertiary institutions in Ekiti State..

\section{Purpose of the Study}

The main purpose of the study was to determine the need for pre-retirement vocational education for workers in tertiary institutions in Ekiti State, Nigeria. Specifically, the study was to:

(a) ascertain the economic needs of preretirement vocational education for tertiary institution workers in Ekiti State.

(b) determine the social needs of preretirement vocational education for tertiary institution workers in Ekiti State.

(c) determine the psychological need of pre-retirement vocational education for tertiary institution workers in Ekiti State.

(d) identify economic ventures/vocations most preferred by tertiary institution

workers after retirement in Ekiti State.

\section{Research Questions}

The following research questions were raised and answered to guide the study.

(1) What are the economic needs for preretirement vocational education training for tertiary institution workers in Ekiti State?

(2) Are there social needs for pre-retirement vocational education training for tertiary institution workers in Ekiti State?

(3) What are the psychological needs for preretirement education for workers in tertiary institution in Ekiti State?

(4) What are the economic ventures/vocations preferred by tertiary institution workers after retirement in Ekiti State?

\section{Method}

The design adopted for the study was descriptive survey design. Osuala (2004) remarks that survey research method is most appropriate for studies which center on individuals and their opinions, beliefs, motivation and behavior. The population of the study was 9,523 , which comprised all the workers (academic and non-academic staff) in the four (4) public tertiary institutions in Ekiti State. They are: Ekiti State University, Ado-Ekiti, the Federal University, Oye Ekiti, College of Education, Ikere Ekiti and the Federal 
Polytechnic, Ado Ekiti. Five per cent (5\%) of the population was adopted as the sample for the study using proportionate sampling technique. Thus, the sample was made up of 476 respondents. One instrument was developed for data collection, a structured questionnaire titled "Questionnaire on Need for Pre-retirement Education for Workers in Tertiary Institutions (QPETTIW) was used for data collection for research questions 1,2 and 3 and an extract of 20 vocations out of the 34 provided by the National Universities Commission, (NUC, 2011). A four point rating scale of Strongly Agree (SA), Agree (A), Strongly Disagree (SD) and Disagree (D) was used for research questions 1, 2 and 3 while Most Preferred (MP), Preferred (P), Less Preferred (LP) and Not Preferred (NP) was used for research question 4 . The split half method was used for the reliability of the questionnaire and the data collected were subjected to
Pearson Product Moment Correlation formula which yielded a coefficient of 0.73 . A total of 476 instruments were administered with the help of one research assistant in each of the institutions and they were all retrieved and analysed using mean and standard deviation. In taking decision for the research questions, any item with the mean of 2.50 and above was considered for 'agreed' or 'preferred' and any item with a mean of less than 2.50 was considered for 'disagreed' or 'Not preferred'.

\section{Results}

In order to answer the research questions, the data collected were presented below:

Research Question 1: What are the economic needs of pre-retirement vocational education for workers in tertiary institutions in Ekiti State?

Table 1: Mean and Standard Deviation of Respondents on Economic Needs of Preretirement Vocational Education Training for Tertiary Institution Workers in Ekiti State. $\mathrm{N}=476$

\begin{tabular}{|c|c|c|c|c|}
\hline $\mathbf{S} / \mathbf{N}$ & Items & Mean & Sd & Decision \\
\hline 1 & Improved innovativeness & 2.55 & 1.07 & Agree \\
\hline 2 & $\begin{array}{l}\text { Exposure to untapped business } \\
\text { opportunities }\end{array}$ & 3.23 & 0.99 & Agree \\
\hline 3 & Additional sources of revenue & 4.87 & 0.34 & Agree \\
\hline 4 & $\begin{array}{l}\text { Contribution to the nation's economic } \\
\text { wealth }\end{array}$ & 3.15 & 0.73 & Agree \\
\hline 5. & Economic use of time & 4.18 & 0.54 & Agree \\
\hline 6. & Acquisition of creative skills & 2.59 & 1.10 & Agree \\
\hline
\end{tabular}

Source: Fieldwork, 2017

Grand mean $=3.43$

Results presented in table 1 showed that, responses in all the 6 items rated above 2.50 which was the acceptable mean score region and thereby indicating agreement with the statements. The grand mean of 3.43 revealed positive responses from the participants on the economic importance of pre-retirement vocational education for sustainability after retirement.

Research Question 2: Are there Social Needs for pre-retirement vocational education training for workers in tertiary institutions in Ekiti State? 
Table 2: Mean and Standard Deviation of Respondents on Social Needs for Preretirement Vocational Education Training for Workers in Tertiary Institutions in Ekiti State. $\mathbf{N}=\mathbf{4 7 6}$

\begin{tabular}{|c|c|c|c|c|}
\hline $\mathbf{S} / \mathbf{N}$ & Items & Mean & Sd & Decision \\
\hline 7 & Improvement in human relation skill & 2.53 & 1.13 & Agree \\
\hline 8 & Improved respect for others (customers) & 2.75 & 0.67 & Agree \\
\hline 9 & Visit to business associates & 3.06 & 0.71 & Agree \\
\hline 10 & $\begin{array}{l}\text { Recognition of change of status (from formal to } \\
\text { informal) }\end{array}$ & 2.17 & 1.09 & Disagree \\
\hline 11 & $\begin{array}{l}\text { Means of indoctrinating family members into } \\
\text { cottage outfit }\end{array}$ & 1.67 & 1.28 & Disagree \\
\hline 12 & Elongated dignity of labour & 2.66 & 1.21 & Agree \\
\hline 13 & $\begin{array}{l}\text { Provision of opportunity in mentoring younger } \\
\text { ones. }\end{array}$ & 3.00 & 0.63 & Agree \\
\hline 14 & Reduction of social vices among adults & 3.65 & 0.69 & Agree \\
\hline
\end{tabular}

Source: Fieldwork, 2017

Grand mean $=2.69$

Results presented in table 2 showed that positive responses generally from the responses of participants in items $7,8,9,12,13$ participants on social needs of pre-retirement and 14 rated above 2.50 of the acceptable training for tertiary institutions workers in Ekiti mean score region, thereby indicating agreement with the statements, except for items 10 , and 11 which rated below the mean score region indicating disagreement with the statements. The grand mean of 2.69 revealed State.

Research Question 3: Are there psychological need for pre-retirement Vocational education for tertiary institution workers in Ekiti State.

Table 3: Mean and Standard Deviation (SD) of Respondents on Psychological Needs for Pre-retirement Vocational education Training for Tertiary Institution Workers in Ekiti State $\mathrm{N}=476$

\begin{tabular}{lllll}
\hline $\mathbf{S} / \mathbf{N}$ & Items & Mean & Sd & Decision \\
\hline 15 & Aligning with low profile lifestyle & 4.58 & 0.83 & Agree \\
16 & $\begin{array}{l}\text { Preparing for and managing of some ageing } \\
\text { health challenges. }\end{array}$ & 4.37 & 0.99 & Agree \\
17 & $\begin{array}{l}\text { Preparation for ageing stereotyping. } \\
18\end{array}$ & 4.65 & 0.53 & Agree \\
19 & $\begin{array}{l}\text { Loneliness is common feature of retirees. } \\
\text { associates because of retirement. }\end{array}$ & 4.23 & 0.57 & Agree \\
20 & Depression is more when close to retirement & 2.56 & 1.03 & Agree \\
\hline
\end{tabular}


B. G. Agboola et al., AJERR, 2020; 5:72

Results presented in table 3 showed that responses in all the six items rated above 2.50 of the acceptable mean score region and thereby indicating agreement with the statements. The grand mean of 3.84 revealed that participants were of the opinion that there is need for pre- retirement vocational training in order to reduce apprehensions that may arise after retirement.

Research Question 4: What are the economic ventures/vocations that will be preferred by tertiary institution workers in Ekiti State after retirement?

Table 4: Preferred Economic Ventures/Vocations by tertiary institution workers in Ekiti State.

$\mathrm{N}=\mathbf{4 7 6}$

\begin{tabular}{lllll}
\hline S/N & ITEMS & Mean & Sd & Decision \\
\hline 21. & Soap/detergent making & 2.36 & 0.77 & Not prefer \\
22. & Cloth Dyeing/Textile & 2.40 & 0.63 & Not prefer \\
23 & Water Treatment and packaging & 3.53 & 0.52 & Prefer \\
24. & Food processing & 3.04 & 1.00 & Prefer \\
25. & Extraction of vegetable oils & 1.99 & 0.99 & Not prefer \\
26. & Aquaculture & 2.67 & 0.73 & Prefer \\
27. & Bakery & 2.13 & 0.88 & Not prefer \\
38. & Photography & 2.23 & 0.55 & Not prefer \\
39. & Block making & 2.41 & 0.89 & Not prefer \\
30. & Paper production & 2.18 & 0.88 & Not prefer \\
31. & Poultry & 3.62 & 0.53 & Prefer \\
32. & Piggery & 2.29 & 0.69 & Not prefer \\
33. & Plumbing & 1.07 & 1.02 & Not prefer \\
34. & Vulcanizing & 1.20 & 0.63 & Not prefer \\
35. & Woodwork and carpentry & 2.13 & 0.54 & Not prefer \\
36 & Welding works & 2.34 & 0.94 & Not prefer \\
37 & Farming & 3.07 & 1.04 & Prefer \\
38 & Tailoring & 2.71 & 0.64 & Prefer \\
39. & Interior decoration & 3.64 & 0.74 & Prefer \\
40. & Printing works & 2.76 & 0.52 & Prefer \\
& & & \\
\hline
\end{tabular}

Source: Fieldwork, 2017

Grand mean $=2.52$

Result presented in table 4 showed that the $26,31,37,38,39$ and 40 rated above 2.50 of the participants' responses in only items 23,24 , acceptable mean score region and thereby https://escipub.com/american-journal-of-educational-research-and-reviews/ 
B. G. Agboola et al., AJERR, 2020; 5:72

indicating that majority of the participants are in agreement to learn only any of these vocations while the other 12 items recorded mean scores of below 2.50. The analysis revealed that most of the vocations listed in the National Policy on Education (NPE, 2013) and the NUC Entrepreneurship Education (2011) are not favourably disposed to by workers in tertiary institutions in Ekiti State.

\section{Discussion of findings}

The findings of the study were based on the four research questions that were formulated for the study. From research question one, it was discovered that 5 items out of the 6 items constructed are in support of economic needs of pre-retirement vocational training for these workers. The items that are highly favoured by respondents are exposure to untapped business opportunities, additional source of revenue, economic use of time, improved innovativeness and contribution to the nation's economic wealth. In support of the above, Umunadi (2010) remarks that the indispensable role that vocational education training plays in equipping individuals with relevant skills and knowledge that will enable people to effectively participate in socio-economic and technological innovation process cannot be over-emphasised. He noted that productive and profitable employments will thereby increase their income levels and access to quality life. Also, in his contribution, in support of the findings, Olateru (2013) observes that vocational education training will contribute positively to reduce poverty, thereby boosting the economic and social status of a nation.

The findings of research question two revealed that six out of the eight items on social needs for pre-retirement vocational training for the workers recorded positive responses. These items include improvement in human relation skills, respect for customers, visit to business associates, reduction of social vices among adults among others. In support of the findings, Okolie and Ogbaekirigwe (2014) remarked that vocation education is a passport to employment and an opportunity for social development for many people. The findings revealed low responses in two items, that is, recognition of change of status and indoctrinating family members into cottage outfit. This shows that most of the respondents are not in support of the items as social needs for preretirement vocational training for tertiary institution workers in Ekiti State.

The findings of research question three revealed that there are psychological needs for preretirement vocational education training for workers in tertiary institutions in Ekiti State as most respondents agreed with all the six items presented for data collection. This shows that most institutional workers are aware of some ageing and health challenges, loneliness, aligning with low profile lifestyle and depression after retirement.

The findings of research question four revealed that only 8 of the 34 vocations listed in the National Policy on Education (2013) and the Entrepreneurship trades in NUC (2011) were most preferred by the respondents. This implies that most of the respondents are not interested in majority of these vocations. Thus, in spite of the realization of the economic opportunities, financial freedom and other benefits derivable from vocational training, only an integral part of the available vocations would be highly concentrated upon while many vocations may not be patronized by most of these workers after retirement. The neglect of most of these vocations may be due to one's attitude, interest, operating environment and nature of the vocation.

\section{Conclusion}

Pre-retirement vocational training has been identified as a means of alleviating the growing concerns and agitations of educational institution workers who are potential retirees in Ekiti State. The result of the study has shown that there are a lot of economic, social and psychological benefits derivable from the training. It is therefore concluded that the introduction of pre-retirement vocational training 
for workers in tertiary institutions in Ekiti State is a worthwhile exercise as it will assist participants to be more relevant in economic and social lives beyond the prescribed government retirement ages. It is also concluded that retirement training will reduce the psychological upsets experienced at post-retirement period due to lack of inadequate planning for retirement.

\section{Recommendations}

Based on the findings of the study, it is recommended that:

(1) Institutional authorities should incorporate pre-retirement vocational training into their staff development programme right from the entry point for improved means of livelihood after retirement from active service..

(2) Authorities of these institutions should occasionally engaged the services of vocational counselors/experts to educate their workers on different available vocations and their hidden economic values.

(3) Institutional workers should not be limited to the available vocations listed in the NPE and NUC as entrepreneurship vocations as most of the vocations were not selected by the respondents.

\section{References}

1. Agboola B.G., Adedokun, M.O. \& Adeyemo, C, W, (2017). Determinants and implications of working past retirement age among adult working population in government parastatals in south west Nigeria. International Journal of Education, Learning and Development, 5(2), 35 - 45.

2. Aina M.A (2019). Educational resources and students acquisition of vocational skills in business studies in Junior Secondary Schools in Ekiti State. International Journal of Current Research 11(3), $2188-2193$.

3. Ali, D.A (2014). Environmental and gender impacts of land tenure regularization in Africa: pilot evidence from Rwanda Journal of Development Economics.

4. Ali, M. (2014), Managing post=retirement conditions in Nigeria. Journal of Good Governance and Sustainable Development in Africa, (JGGSDA), (2)2, $110=121$.

5. Becker, M. T., Trail, T, F., Lamberts, M. B. \& Jimmerson, R. M., (1983). Is pre-retirement planning important? Journal of Extension. 12, 10
-14 .

6. Kim, S. \& Feldman, D. C. (2000). Working in retirement: The antecedents of bridge employment and its consequences for quality of life in retirement. Academy

of Management Journal, 43, 1195- 1210.

7. Kleop, M. \& Hendry, L. B.(2007). Lifespan Development: Resources, Challenges and Risks. Britain, Cengage Learning EMEA.

8. National Universities Commission, (2011). Benchmark minimum academic standard for undergraduate programmes in Nigerian universities, GST Entrepreneurship, Abuja.

9. Odu, B.K, Ayodele C.J and Adedayo J.O (2014). Empowering the youths for sustainable national development through vocational education in South West Nigeria. International Journal of Educational Research and Development 3(1), 001 $-005$.

10. Okolie, U.C. \& Ogbaekirigwe, C. (2014). Entrepreneurship Development through Vocational Education Training: Issues and roles in skills acquisition and manpower development in a developing economy. Journal of Educational Policy and Entrepreneurial Research, 1(2), 151-157.

11. Olateru, E.O. (2013). Towards an effective entrepreneurship Training in Technical and Vocational Education and Training in a developing Economy. Technology Education Journal, 9(1) 98-100.

12. Ubangha, M. B. \& Akinyemi, B. A, (2005). The relationship between attitudes to retirement planning and retirement anxiety among teachers. The Counselor, 21, 156 - 163.

13. Umunadi, K.E. (2010). Acquisition of skills and Competencies by Technical Education Teachers as Instrument for National Growth in Nigeria. Journal of Qualitative Education, 6(1), 3-4. 